Testing take-up of academic concepts in an influential commercial tourism

publication

Ralf Buckley

International Centre for Ecotourism Research, Griffith University, PMB 50 Gold Coast

Mail Centre, Australia. r.buckley@griffith.edu.au Tel +61.7.55528675

Fax +61.7 .55528895$

Total number of words: 5446 
Testing take-up of academic concepts in an influential commercial tourism publication 


\begin{abstract}
Many independent travellers read and rely on the Lonely Planet ${ }^{\circledR}$ destination guidebooks. In 2006 the company published two global selections which effectively define its perspectives on adventure, culture and ecotourism. By analysing the content of these volumes, we can test whether information reaching individual tourists is congruent with relevant theoretical constructs. Broadly, it is: but it is less precise, comprehensive or up-to-date than published research, and relies more on example than synthesis. In addition, it has a strong emphasis on social aspects, commonly described as community ecotourism. Opportunities such as this, to analyse the affects of academic tourism research on commercial tourism publishing, are relatively rare.
\end{abstract}

Keywords: adventure, code, destination, ecotourism, guidebooks, responsible

\title{
1. Introduction and Methods
}

A key feature of any science is the testing of models and hypotheses against observations. In the social sciences this generally involves observations of human behaviour. In tourism studies, it involves testing the actual behaviour of humans as tourists, against theoretical models for that behaviour. One of the more powerful measures to test any model is to use that model to predict the outcome of a disturbance or intervention in the system under study, and then to test those predictions against observed changes when that disturbance actually occurs. In the tourism industry, some such disturbances are generated externally, and some internally. External disturbances include, e.g.: fuel price rises; increased security risks from terrorist attack or armed conflict; increased health risk through disease epidemics; or increased access 
opportunities through new infrastructure or technology. Internal disturbances include, e.g.: construction of new tourist accommodation or attractions; development of new activities; or new marketing campaigns, including the wide variety of ecolabelling, branding and certification schemes.

Academic research and writing about tourism may in itself be viewed as an intervention in the behaviour of humans as tourists and tour providers. Most academic analysis of the tourism industry is a one-way street: academics observe tourists and the tourism providers, but the latter pay little attention to such analyses, which in general necessarily lag behind the changes in human society and behaviour which they set out to study. This contrasts with many of the natural sciences, for example, where changes in human society and behaviour are driven in part by new technologies and policies, which in turn are derived from new scientific information obtained by academic analysis of the natural world.

Cases where the tourism industry may have changed specifically in response to academic analysis should therefore be of particular theoretical interest. In such cases, academic writings may be seen as an intervention in the tourism industry, whose results may then themselves be subject to academic scrutiny. One such case is described here.

There has been a considerable volume of academic writing on the topic of ecotourism, much of it devoted to defining the term (Weaver, 2001). There have also been a number of attempts to compare individual commercial tourism products which market themselves as ecotourism, against academic or government definitions, to see how well or poorly they comply (Buckley, 2003a). In theory, ecotourism certification schemes make the same comparison, but within a commercial rather than an academic 
framework; and there are also academic analyses of the degree to which such ecocertification processes and ecocertified products comply with academic definitions of ecotourism (Font and Buckley, 2001; Font, 2002).

Recently, a new and different opportunity has become available to test the commercial uptake of academic theory in ecotourism. The very well-known tourism publisher Lonely Planet ${ }^{\circledR}$ has published two books which include both text descriptions, and product selections, illustrating Lonely Planet's commercial and related terms. By examining the content of these volumes we can test the degree to which an influential commercial tourism organisation has adopted academic views on a particular tourism topic. As noted earlier, such opportunities are relatively rare. This particular comparison is all the more interesting since the Lonely Planet books themselves make very little reference to academic publications.

Lonely Planet ${ }^{\circledR}$ guidebooks are relied upon routinely by independent travellers worldwide as a key to accommodation, transport and activities in particular destination regions. The guidebooks have moved increasingly upmarket in recent years, featuring luxury as well as backpacker options, and commercial tours as well as budget options. This may be part of the company's competitive publishing strategy. Alternatively, this may simply reflect the aging of its original customer base, who may now be cash-rich but time-poor rather than time-rich but cash-poor.

During 2006, Lonely Planet published a set of 82 case studies in ecotourism under the title of Code Green (Lorimer et al., 2006). Under the title Blue List, it also published a set of 26 top-10 lists under a wide variety of themes, including ecolodges and extreme 
environments, nature and remote areas, adrenalin rushes and sustainable tourism, treks and wildlife watching.

From a methodological perspective, there are three types of relevant content in the two Lonely Planet volumes. Firstly, there are sections of text which express the views of Lonely Planet authors directly. These include, for example, the introductory pages and a number of text boxes in each book. Secondly, the selection of case studies and top-10 lists in themselves reveal Lonely Planet perspectives. And thirdly, at least in Code Green, each case study includes a list of credentials, effectively reasons why it was selected.

Here, therefore, all three of these components are analysed to determine whether Lonely Planet ${ }^{\circledR}$ defines ecotourism in the same way as academic researchers.

\section{Results}

\subsection{Criteria and Definitions}

Code Green claims to be about so-called responsible tourism rather than ecotourism as such. Responsible tourism is a rather vague term, at least potentially susceptible to the same shortcomings as the chemical industry's "Responsible Care" initiative, critiqued by Gunningham and Grabowsky (1998). The term does not appear to have been analysed in the research literature to the same extent as ecotourism, though it has been promoted by particular authors such as Chemish (1998), Sirakaya et al. (1999), Goodwin and Francis (2003) and Medina (2005). The definition used by Goodwin's International Centre for Responsible Tourism (2006) is that "responsible tourism: minimises negative economic, environmental, and social impacts; generates greater 
economic benefits for local people and enhances the well-being of host communities, improves working conditions and access to the industry; involves local people in decisions that affect their lives and life chances; makes positive contributions to the conservation of natural and cultural heritage, to the maintenance of the world's diversity; provides more enjoyable experiences for tourists through more meaningful connections with local people, and a greater understanding of local cultural, social and environmental issues; provides access for physically challenged people; and is culturally sensitive, engenders respect between tourists and hosts, and builds local pride and confidence". This definition is thus highly congruent with accepted definitions of ecotourism (Buckley, 1994, 2003a; Weaver, 2001).

According to the concept put forward in Code Green, responsible travel "can be more-or-less defined as travel that takes into consideration ... 'triple bottom line' issues". Code Green is vague as to how such a triple bottom line should actually be assessed, but some of these technical issues have been considered by Buckley (2003b). In most formulations of this concept, however, the economic component of the triple bottom line refers to commercial viability. Lonely Planet, in contrast, seems to mean an economic contribution to host communities through local retention of revenue. This is an equally significant but conceptually distinct issue, often considered as part of the social rather than the economic bottom line (Buckley, 2003b).

The way Code Green expresses triple-bottom-line issues is as follows. "Environment: Travel that minimises negative environmental impacts and, where possible, makes positive contributions to the conservation of biodiversity, wilderness, natural and human heritage. Where travellers and locals learn and share information, leading to better appreciation and understanding. Social/Cultural: Travel that respects culture and 
traditions and recognises the rights of all peoples to be involved in decisions that affect their lives and to determine their future. By involving and engaging local people, there is authentic interaction and greater understanding between travellers and hosts, which builds cultural pride and community confidence. Economic: Travel that has financial benefits for the host community and operates on the principles of fair trade. Monies spent by travellers remain in the community through the use of locally owned accommodation, staff and services; funding community initiatives, training or other in-kind support.”

This approach includes the minimal-impact and conservation-contribution components common to most ecotourism definitions (Buckley, 1994; Weaver, 2001). It also includes the community-contribution component included by some (Scheyvens, 1999; Wearing and McLean, 1997; Wearing and Neil, 1999; Wearing and McDonald, 2002; Jones, 2005; Kontogeorgopoulos, 2005). It says nothing, however, about guided interpretation, considered as critical by some commentators (Black and Ham, 2005). This omission might be due to the Lonely Planet emphasis on independent travel, except that many of the case studies cited are fully guided commercial tours.

\section{$2.2 \quad$ Text Boxes}

Code Green contains a number of text boxes covering issues, institutions and quandaries which independent travellers might face in their quest for responsibility. On the social side, for example, it describes the role of the International Porter Protection Group in the Himalayas, an organisation dedicated to the welfare of porters and climbing Sherpas and supported by a number of trekking and climbing tour operators. The extremely difficult issue of how best to respond to begging is also addressed. This 
goes well beyond most academic analyses of ecotourism or sustainable tourism, with a few exceptions such as Mowforth and Munt (1998).

Three of these text boxes examine some of the environmental aspects of travel and tourism. One of these refers the reader to commercial organisations who will plant trees if you pay them, supposedly to offset carbon dioxide emissions associated with holiday travel. These schemes, however, may simply be a way for plantation owners to profit at the expense of guilt-ridden and gullible travellers. It is difficult to see that they make a serious contribution to conserving the natural environment. From an environmental perspective, a much more effective use of such funds would be to buy out logging leases or conduct political lobbying against the continuing logging of old-growth forest, especially in developing nations. This, however, would require representatives of the tourism industry to take a public stand against unsustainable practices in other sectors. To date, very few individual companies have been prepared to take this approach (Buckley 2003a). Whether or not such tree planting schemes are much actual use, however, they are widely touted as such and we can hardly expect Lonely Planet to make a critical analysis on its own account.

Code Green offers three tips for travellers to tell if holidays are "green or just greenwash". The first is that operators who are serious about environmental and cultural issues ought to have a written policy, advertised openly or readily available on request. The third is that operators who make a contribution to conservation or culture are commonly proud to talk about it, at least if you ask them. And the second is that, in Lonely Planet's view, operators ought to do all of the following, and be able to demonstrate it: recycle waste; avoid overcrowding; employ local guides; train guides in minimal-impact practices and interpretative skills; provide clients with educational 
materials on environment and culture; limit group sizes; purchase goods and services locally and fairly; use family-owned and minimal-impact accommodation; leave a large proportion of revenue with the local community; and establish or assist in local conservation projects or charities.

These are good criteria for ecotourism, but not easy to use in practice. Some operators who have excellent credentials prefer not to boast about them, whereas others may make a conspicuous display of credentials which are largely fudged or faked. Again, however, these are difficulties faced by any ecotourism auditor, certification scheme or researcher (Font and Buckley, 2001; Buckley, 2003). The criteria put forward by Lonely Planet may be hard to apply in practice, but they do indeed match with those which might be used by academic ecotourism auditors.

For the independent wilderness hiker and camper, Code Green provides a list of minimal-impact practices, as summarised in Table 1. There are one or two additional instructions in the book's introduction and endnotes: for example, don't buy artefacts made from wild animals or plants; don't approach wildlife too closely; and leave extra packaging at home. These recommendations are considerably less detailed than minimal-impact guidelines provided by protected area management agencies, ecotourism associations or research organisations (Buckley, 2002). There are also a few points where the Code Green recommendations differ from standard practices. For example, most minimal-impact codes would suggest the use of a fuel stove rather than a campfire wherever possible. Similarly, whilst there was a short-lived fashion for burning toilet paper, this is no longer recommended except perhaps in alpine or polar environments: in dry areas it carries a fire risk, in wet areas the paper will rot anyway. In addition, these minimal-impact guidelines are restricted to hiking. For a book about 
responsible tourism, this seems inadequate. Minimal-impact materials are now freely available for a wide range of different outdoor activities, not only for hiking and camping (Buckley, 2002). Given that the case studies in Code Green cover a considerable range of activities, and specifically include bicycling, boating and kayaking these educational materials could easily have been more extensive.

\section{[INSERT TABLE 1 NEAR HERE]}

\subsection{Products Featured}

The most reliable indication of the Code Green perspective on ecotourism or responsible tourism can be derived not from the editorial material such as text boxes, but from the particular products featured and the credentials listed for each. These are summarised in Table 2. The case studies presented range quite widely in both price and duration (Figures 1 and 2).

[INSERT FIG 1 NEAR HERE]

[INSERT FIG 2 NEAR HERE]

Of the 82 case studies described, five involve a private or community conservation reserve, either terrestrial or marine. Several contribute to public protected areas through fees, funds for rangers, or volunteering. Five encourage lobbying against environmental damage by other industry sectors. Eight benefit wildlife, eg through reintroductions or reduced poaching. Eight contribute to research. Twenty-one claim minimal-impact operations of some form, whether through rules, technologies, quotas or management. All of these represent contributions to the environmental bottom line. 
In 11 of the case studies, the operators concerned hire local guides, and in 18 the tours contribute to local employment less directly. Eight contribute cash directly to local residents; four fund projects to benefit locals; and seven support schools or other educational efforts. All of these represent local economic contributions, which may be viewed as part of the social bottom line. Twelve of the case studies involve cultural interactions and/or interpretation, though these may provide social benefits mainly for the tourists rather than the locals.

The selection is very broad, with perhaps a little under $50 \%$ potentially qualifying as ecotourism under more stringent definitions. About $15 \%$ are volunteering opportunities, and a little over one third have a strong social focus. Monopoly guiding rights for particular local groups seem to be especially emphasised. This represents a particular viewpoint, not necessarily justified by demonstrable social, environmental or even economic benefits.

[INSERT TABLE 2 NEAR HERE]

\section{$2.4 \quad$ Blue List}

There are two main parts to the Lonely Planet Blue List. The first third consists of worldwide top-10 lists in various categories; and the remaining two thirds consists of country-by-country summaries, including lists of "what's hot" for each. Both ecotourism and adventure products and destinations are featured, but not exclusively. Top-10 lists relevant to ecotourism and adventure travel are summarised in Table 3. 
[INSERT TABLE 3 NEAR HERE]

Four of the top-10 lists are relevant to ecotourism: those for wildlife, natural attractions, sustainable travel and ecolodges. The top-10 list for wildlife watching includes Kenya, Malaysian Borneo, Madagascar, Belize, Botswana, Costa Rica, the US Everglades, Australia's Great Barrier Reef, Bolivia and the Galapagos Islands in Ecuador. All of these are mainstream wildlife tourism destinations.

Under spectacular natural attractions, the Lonely Planet picks include two deserts, a giant salt lake, a canyon, a coral reef, a mountain range, two lake districts and a waterfall (Table 3). Commercial nature tours are offered in, or to, all of these.

One of the most revealing of the top-10 lists is the selection for sustainable travel. The list includes two conservation volunteer programmes, a variety of hiking and wildlife-watching experiences, an ecolodge and a seakayak tour, Antarctic cruising, and a fly-in tour to an Australian Aboriginal rock art site (Table 3). Top of the list is an interpretive walk with San Bushmen in the Kalahari. As with all these lists, no reasons are given for these particular selections. Many of them have been described in the tourism research literature and would indeed comply with mainstream definitions of sustainability. The environmental costs of transport, however (Simmons and Becken, 2004; Gössling and Hultman, 2006), do not seem to have been a major consideration.

To pick the world's top 10 ecolodges would be a daunting task for any ecotourism researcher, but the Blue List makes a bold attempt nonetheless (Table 3). Some of them have been described in detail in the tourism research literature, others not. Price was clearly not a consideration, with some of the selections at the luxury end of the market. 
Whilst the precise picks and ranks would certainly be open to debate, the list does seem to indicate that the Lonely Planet conception of an ecolodge is indeed congruent with that used in the research literature.

Five of the lists are relevant to adventure travel: treks, extreme environments, remote areas, adrenalin rushes and so-called tough-travel destinations. Some of the treks selected for the Blue List are relatively easy, others quite the reverse. Most are available as commercial adventure tours. Under the heading of extreme environments, Lonely Planet lists four deserts, four mountain ranges and two cities (Table 3). There are commercial tours to most of these, though the city destinations would not be marketed as adventure.

Remote is a relative term. All but two of the regions nominated by Lonely Planet (Table 3) are routinely accessible by scheduled transport; though access on the ground can be more demanding. Even so, it seems difficult to justify the listing of Perth, Australia, as remote under any but the most Eurocentric of definitions. Perhaps six of the areas listed are routinely included in commercial adventure tours.

The list of adrenalin rushes is wide-ranging. It includes passive terror, whether involuntary as for a taxi ride in Thailand, or voluntary as for a theme park ride in Las Vegas (Table 3). There are safe but perhaps potentially unnerving experiences such as parasailing and the Sydney Harbour Bridge climb. There are well-managed and heavily-commercialised but still potentially risky tours such as swimming with sharks or rafting the Zambezi. And there are highly active and participatory options such as rock climbing at Yosemite, or running with the bulls in Pamplona: an adrenalin-charged experience even for veterans of the event. 
Ten countries are picked as particularly dangerous, whether for wars, terrorism, street crime, or kidnappings (Blue List, pp. 32-33). Despite such negative press, commercial tours do indeed visit Pakistan, Afghanistan, Algeria, Yemen and so on, though possibly not Dagestan.

The country-by-country component of the Blue List focuses mostly on modern culture and conveys rather little about Lonely Planet perceptions of ecotourism and adventure travel, or even cultural tourism in the ACE sense of Fennell (1999, p.53). Scenic splendours are mentioned for Argentina and Iceland; national parks for Chile and El Salvador; adventure activities for Ecuador and Ethiopia; wildlife watching in Botswana, Madagascar and Tanzania; diving in Belize and Oman; and trekking and hiking in Peru, Nepal, Tibet, the UK, Jordan and New Zealand. These do not seem to be representative selections either of the countries where particular activities are available, or the activities available in particular countries. Little, therefore, can be deduced from this section of the book.

\section{Conclusions}

Lonely Planet publications are written for retail sale to individual travellers, whether they make their own way or take commercial tours. They are not intended as analytical texts. Whether by example or exhortation, however, they do embody a particular philosophy of nature and adventure travel and associated cultural interaction. The top-10 picks in the Blue List are perhaps too brief and eclectic to make any reliable

judgement as to how Lonely Planet defines adventure or ecotourism, but at least they do 
not seem to be severely out of line with academic concepts. Code Green contains a great deal more information and some more definitive conclusions can be drawn.

Lonely Planet seems to make little use of analytical research literature, instead relying rather uncritically on readily-accessible websites which claim some kind of green-travel credentials. Some of these sources are reliable, others rather less so. Perhaps ironically, whilst generally urging independent travellers to do their homework thoroughly, Lonely Planet may not have done its own as well as it might. This applies also to its minimal-impact recommendations. In listing criteria for travellers to distinguish green from greenwash, Lonely Planet is more comprehensive but focuses strongly on social aspects such as local purchasing. There is perhaps some contradiction with its endorsement of, for example, a luxury resort in Dubai, which may well contribute to a private conservation reserve but is unlikely to source all its supplies in local communities.

The richest source of data, however, is the selection of the 82 studies themselves, and the justification given for each. Only about half of these would probably qualify as ecotourism under academic criteria.

Overall, it would appear that whilst the messages conveyed to individual travellers through these guidebooks are not contradictory to concepts and constructs in the research literature, the Lonely Planet approach is rather broader and less precise; and perhaps most importantly, it has a stronger emphasis on social rather than ecological aspects, what has been described elsewhere as community ecotourism. That is, ecotourism as presented to retail purchasers of the Lonely Planet guides is broadly, but by no means accurately, based on academic constructs of ecotourism. 
The approach reported above represents only a single test using a single commercial entity, albeit an influential one. In addition, it tests only how well academic concepts of ecotourism are represented in a retail-level commercial tourism publication aimed at independent travellers, and not how well those travellers actually follow the principles set out in that publication. Despite these limitations, it provides a useful test of feedback links between commercial tourism and academic analysis. If tourism theories are to remain grounded in real-world tourism practices, such feedback links, and the opportunities to test them, are of critical significance.

\section{References}

Black, R., \& Ham, S. (2005). Improving the quality of tour guiding: towards a model for tour guide certification. Journal of Ecotourism 4, 178-195.

Buckley, R. C. (1994). A framework for ecotourism. Annals of Tourism Research, 21, 661-665.

Buckley, R. C. (2002). Minimal impact guidelines for mountain ecotours. Tourism Recreation Research 27(3), 35-40.

Buckley, R. C. (2003a). Case studies in ecotourism. Wallingford: CABI.

Buckley, R. C. (2003b). Environmental inputs and outputs in ecotourism: geotourism with a positive triple bottom line? Journal of Ecotourism 2, 76-82. 
Chemish, W. N. (1998). Practising responsible tourism: international case studies in tourism planning, policy and development. International Journal of Hospitality Management 17, 427-430.

Fennell, D. (1999). Ecotourism: an introduction. New York: Routledge.

Font, X. (2002). Environmental certification in tourism and hospitality: progress, process and prospects. Tourism Management 23, 197-205.

Font, X., \& Buckley, R. (2001). (Eds.), Tourism ecolabelling. CABI: Wallingford.

Goodwin, H., \& Francis, J. (2003). Ethical and responsible tourism: consumer trends in the UK. Journal of Vacation Marketing 9, 271-284.

Gössling, S., \& Hultman, J. (2006). (Eds.), Ecotourism in scandinavia: lessons in theory and practice. CABI: Wallingford.

Gunningham, N. \& Grabowsky, P. (1998). Smart regulation. Oxford: Clarendon.

International Centre for Responsible Tourism. (2006). Responsible tourism. http://www.icrtourism.org/resp.html [15 August 2006].

Jones, S. (2005). Community-based ecotourism: the significance of social capital. Annals of Tourism Research, 32, 303-324. 
Kontogeorgopoulos, N. (2005). Community-based ecotourism in Phuket and Ao Phangna, Thailand: partial victories and bittersweet remedies. Journal of Sustainable Tourism, 13, 4-23.

Lonely Planet. (2006). Blue list. Melbourne: Lonely Planet Publications.

Lorimer, K. (2006). Code green. Melbourne: Lonely Planet Publications.

Medina, K. L. (2005). Ecotourism and certification: confronting the principles and pragmatics of socially responsible tourism. Journal of Sustainable Tourism, 13, 281-295.

Mowforth, M., and Munt, I. (1998). Tourism and sustainability. London: Routledge.

Scheyvens, R. (1999). Ecotourism and the empowerment of local communities. Tourism Management, 20, 245-250.

Simmons, D. G., \& Becken, S. (2004). The cost of getting there: impacts of travel to ecotourism destinations. In R. C. Buckley (Ed.), Environmental impacts of ecotourism (pp. 15-23). Wallingford: CABI.

Sirakaya, E., Sasidharan, V., \& Sonmez, S. (1999). Redefining ecotourism: the need for a supply-side view. Journal of Travel Research, 38, 168-172.

Wearing, S., \& McDonald, M. (2002). The development of community-based tourism: rethinking the relationship between tour operators and development agents as 
intermediaries in rural and isolated area communities. Journal of Sustainable Tourism, 10, 191-206.

Wearing, S., \& McLean, J. (1997). Development of ecotourism: a community-based approach. Melbourne: HM Leisure Planning.

Wearing, S., \& Neil, J. (1999). Ecotourism: impacts, potentials and possibilities. Oxford: Butterworth-Heinemann.

Weaver, D. (2001). (Ed.), The encyclopaedia of ecotourism. Wallingford: CABI. 
Table 1: Minimal-impact Hiking Practices Recommended by Lonely Planet Code Green.

"stay on existing trails even if muddy, don't shortcut;

walk on rocks or hard soil rather than plants, especially at high altitudes and latitudes;

carry out rubbish, including cigarette butts and tampons;

pick up others' rubbish;

don't buy bottled water, boil or purify your own;

camp on sand or leaf litter, not alpine meadows;

don't dig ditches;

camp at least 30 metres from any lake or stream;

bury human waste at least $15 \mathrm{~cm}$ deep and 100 metres from any trail or watercourse;

burn toilet paper;

carry water at least $50 \mathrm{~m}$ from the source for washing;

use only biodegradable soaps and shampoos;

don't swim upstream from local water collection points;

light fires only in existing sites and where permitted;

burn only dead fallen timber and keep fires small;

don't put batteries or plastic in fires;

extinguish, cover and disguise fires before leaving. 
Table 2 Lonely Planet ${ }^{\circledR}$ Code Green Case Studies

$\begin{array}{lll}\text { Country } & \text { Place } & \text { Tour Operator } \\ \text { Cameroon } & \text { Bamenda } & \text { Birding Africa } \\ \text { Dubai } & \text { Al Maha } & \text { Al Asha Resort } \\ \text { Egypt } & \text { South Sinai } & \text { Mountain Tours } \\ \text { Ethiopia } & \text { Simien Mts } & \text { Peregrine Adv } \\ \text { Senegal } & \text { Abene } & \text { Various local } \\ \text { Jordan } & \text { Wadi Mujib } & \text { RSCN (parks) } \\ \text { Kenya } & \text { Leroghi Mts } & \text { Sambuni Treks } \\ \text { Madagascar } & \text { Ranomafana } & \text { Earthwatch } \\ \text { Mali } & \text { Dogon Country } & \text { Toguna Adv } \\ \text { Morocco } & \text { Atlas Mts } & \text { Kasbah du Toubkal } \\ \text { Mozambique } & \text { Lake Nyasa } & \text { Nkwichi Lodge } \\ \text { Namibia } & \text { Damaraland } & \text { Wilderness Safaris }\end{array}$

Namibia

\section{Main Credentials Claimed}

Pay for rangers, local artefacts

Private reserve, reintroductions, $5 \%$ of profits to conservation projects

Jabaliya Bedouin guide monopoly

World Heritage, gate fees, job equity

Learning drums in campements

Quotas, local guides, reintroductions

Low-impact camps, funds to local schools

Sifaka research by volunteers

Local guides, cultural interpretation

Local jobs, community projects

Less poaching, burning; local jobs, US $\$ 5$ per bed night to Community Trust

Community conservation area, increased wildlife populations, local jobs, $10 \%$

of room revenue to schools and stock compensation

US\$12,000 pa to local villagers 


\begin{tabular}{|c|c|c|c|}
\hline Uganda & Burundi NP & Discovery Initiatives & Park funding, local jobs, US $\$ 20$ per person to projects \\
\hline South Africa & Capetown & Various & Local tours, accommodation \\
\hline South Africa & Pretoria & De Wildt Centre & Cheetah and other wildlife conservation \\
\hline Tanzania & Chumbe Island & Chumbe Resort & Low impact, private marine reserve, education \\
\hline Zambia & Zambezi & Exodus & Low-impact camps, local jobs \\
\hline Bhutan & Paro & Yangphel & High visa fees to government \\
\hline Borneo & Batang Ai NP & Borneo Adventure & Village tourism, education fund \\
\hline East Timor & Atauro Island & Tua Koin & Recycling, solar power, water conservation \\
\hline India & Uttaranchal & Kumaon & Village-to-village walk, local guides \\
\hline India & Ladakh & World Expeditions & Minimal-impact camping, local guides \\
\hline India & Pench Tiger Reserve & Discovery Initiatives & US\$68 per tour to tiger NGOs; meeting village elders \\
\hline India & Varanasi & Yoga Schools & Interact with locals \\
\hline Japan & Iriomote & Mayagusuku & Interpretation, alternative to large-scale beach resorts \\
\hline Kyrgyzstan & Bishkek & CBT & Low impact horse trek, local accommodation \\
\hline Mongolia & Arhangai & Ger-to-Ger & Small groups, aid-funded project, $65 \%$ of trip goes to local herders \\
\hline Nepal & Mustang & CRTP & Temple restoration funded by tours \\
\hline
\end{tabular}




\begin{tabular}{|c|c|c|c|}
\hline Nepal & Rolwaling & Peregrine Adv & Trekking toilets, microhydro power \\
\hline Sri Lanka & Unawatuna & Local & Independent travel, local expenditure \\
\hline Tajikistan & Pamir Mts & MSDSP & Aid-funded project, local yurts, crafts \\
\hline Thailand & Bon Kingkaew & World Endeavours & Volunteering in orphanage \\
\hline Thailand & Phuket & Gibbon Rehabilitation & Gibbon rehab centre inside park \\
\hline Australia & Kimberley & Kooljaman & Indigenous equity, profits to Bardi people \\
\hline Australia & Ingram I & Earthwatch & Volunteering for hawksbill turtle research \\
\hline Australia & Lord Howe Is & Various local & World Heritage, quota, bicycles, recycling \\
\hline Australia & Arnhem Land & Davidsons & Mt Borradaile Aboriginal rock art site \\
\hline Australia & Ningaloo & Ningaloo Blue & Whalesharks, park rules \\
\hline Australia & Sydney Harbour & Natural Wanders & Seakayak tour, yacht crewing \\
\hline Australia & Red Centre & World Expeditions & Minimal-impact, hiking, composting toilets at park camps \\
\hline Australia & Tasmania & Tarkine Trails & Lobby against logging \\
\hline Australia & Uluru & Anangu Tours & Aboriginal interpretation, revenue \\
\hline New Zealand & Kaikoura & Whale Watch Kaikoura & Maori owned, exclusive rights \\
\hline New Zealand & Waipoua & Footprints Waipoua & Maori owned, exclusive rights \\
\hline
\end{tabular}




\begin{tabular}{|c|c|c|c|}
\hline England & Coast-to-Coast & FIT cycling & Low-impact transport, local interactions \\
\hline Finland & Oulanka NP & Metsahallitus & PAN Parks; trails, cabins \\
\hline Greenland & Tasiilaq & Tuning Incoming & Local hunters as guides \\
\hline Ireland & Lough Derg & CELT & Forestry education, NFP \\
\hline Poland & Bialowieza & Various, local & European bison, licensed guides, local culture, lobby against logging \\
\hline Romania & Carpathian Mts & Exodus, CLCP & Bear and wolf conservation \\
\hline Romania & Danube Delta & Various, local & World Heritage, local expenditure \\
\hline Russia & Lake Baikal & Earth Island Institute & Volunteer, trail construction, environmental monitoring \\
\hline Switzerland & Alps & Naturetrek & Wildflower walks, family hotel \\
\hline Canada & Arctic Guide & Frontiers Foundation & Volunteering, housing and schools \\
\hline Canada & Vancouver I & Pacific NW & Orca seakayak, whalewatch rules, research \\
\hline Canada & Saskatchewan & Two Worlds of Horse & Cattle ranching, Cree family \\
\hline USA & Bluff, UT & Llama Pack & Llama tours, Anasazi ruins \\
\hline USA & Grand Canyon & Xanterra & Winter mule rides, off-season visit \\
\hline USA & Maine & J \& E Riggin & Sailing windjammers, leave-no-trace policy \\
\hline USA & Route 66 & Car Rental & Small-town travel \\
\hline
\end{tabular}


USA

USA

Fiji

Micronesia

Nan Madol

Palau

Rock Islands

Tonga

Vava'u

Antarctica

Peninsula

Bahamas

Bolivia

Brazil

Chile

Chile

Cuba

Ecuador

Havana

Galapagos Is
Sierra Club

USNPS

Southern Sea Ventures

Local Trips

Various

Whaleswim Adventures

IAATO members

Starfish

Chalalan

Earthwatch

Mountain Travel Sobek

Torres del Paine NP
Volunteer trail maintenance

Volunteer research on bears, bison, wolves

Seakayak, minimal impact, local accommodation, education fund, fees to

$$
\text { villages }
$$

Snorkelling, ruins, locals

Live-aboard dive charters

Permit system, quotas, research, lobby against whaling

Antarctic Treaty, MARPOL, 4-stroke outboards, research

Marine reserve, conservation, low infrastructure, local operators

Conservation of flora and fauna, supports 74 Indigenous families

Conservation Research Initiative with Conservation International; research on giant otters

Rafting, US\$10 per trip to lobby against dams

Horseriding tours, local wranglers, local supplies

Casa particulares, local accommodation

Parks service naturalist guides, US $\$ 40$ per visitor to parks service 
Ecuador

Guatemala

Antilles

Peru

Venezuela
Amazon R

Antigua

St Eustatius

Tambopata

St Elana de Uairen
Kapawi Ecolodge

Various

Stenapa

Biosphere Expeditions

Various
Revenue to local communities

Volunteer schoolteaching

Volunteering for parks service, diving

Volunteer research, carbon offsets

Volunteering in schools and conservation projects 
Table 3 Lonely Planet ${ }^{\circledR}$ Blue List Top-Ten Lists

\begin{tabular}{|c|c|c|c|c|c|c|c|c|c|}
\hline No & Wildlife & Remote & Tough & Extreme & Treks & Spectacular & Sustainable & Ecolodges & Adrenalin \\
\hline 1 & \multirow[t]{2}{*}{ Kenya } & Death & Pakistan & Sahara, Mali & Everest & Atacama, Chile & Tsumkwe, & Alandaluz, & \multirow[t]{2}{*}{ Bull run, Spain } \\
\hline & & Valley, USA & & & Base, Nepal & & Kalahari & Ecuador & \\
\hline \multirow[t]{2}{*}{2} & \multirow[t]{2}{*}{ Borneo } & \multirow[t]{2}{*}{ Antarctica } & \multirow[t]{2}{*}{ Colombia } & Atacama, & Inca Trail, & Lake District, & Cruising & Basata, & Shark swim, \\
\hline & & & & Chile & Peru & England & Antarctica & Egypt & South Africa \\
\hline \multirow[t]{2}{*}{3} & \multirow[t]{2}{*}{ Madagascar } & Siberia, & \multirow[t]{2}{*}{ Afghanistan } & Danakil, & GR20, & Milford Sound, & \multirow[t]{2}{*}{ Seakayak, Fiji } & Nikita's, & Zambezi raft, \\
\hline & & Russia & & Ethiopia & France & New Zealand & & Russia & Zimbabwe \\
\hline \multirow[t]{2}{*}{4} & \multirow[t]{2}{*}{ Belize } & Barrow, & \multirow[t]{2}{*}{ Algeria } & Outback, & Pays Dogon, & Plitvice Lakes, & Park Volunteer, & Daintree, & Parasail, \\
\hline & & Alaska & & Australia & Mali & Croatia & USA & Australia & Mexico \\
\hline \multirow[t]{2}{*}{5} & \multirow[t]{2}{*}{ Botswana } & Cliffs of & \multirow[t]{2}{*}{ Dagestan } & Banff NP, & Himalayas, & Angel Falls, & Carpathian & Blumau, & Rock climb, \\
\hline & & Moher, & & Canada & India & Venezuela & Carnivores & Austria & Yosemite USA \\
\hline
\end{tabular}


Ireland

Jan Mayen
Is, Norway

Haiti

Ladakh

Overland,

Sossusvlei,

India

Tasmania

Namibia

Mexico City, Routeburn,

Grand Canyon,

Mexico

New Zealand USA

Andes,

Narrows,

Rocky Mts,

Ecuador

Zion, USA

Canada

Chalalan,

Bolivia

Chanzania

Tanzania

Theme-park

Reef, Australia

Easter Is,

Sierra Leone

Delhi, India

\section{Chile}

10 Galapagos,

Perth,

Ecuador

Australia
Alaska

Baltoro-K2, Great Barrier

Range, USA Pakistan
Reef, Australia New Zealand
Arenal, Bridge climb,

Costa Rica Sydney

Turtle Is, Moto-taxi,

Fiji Thailand 


\section{Figure Legends}

Figure 1 Price distribution of Code Green selections

Figure 2 Distribution of tour length Code Green selections 
Figure 1

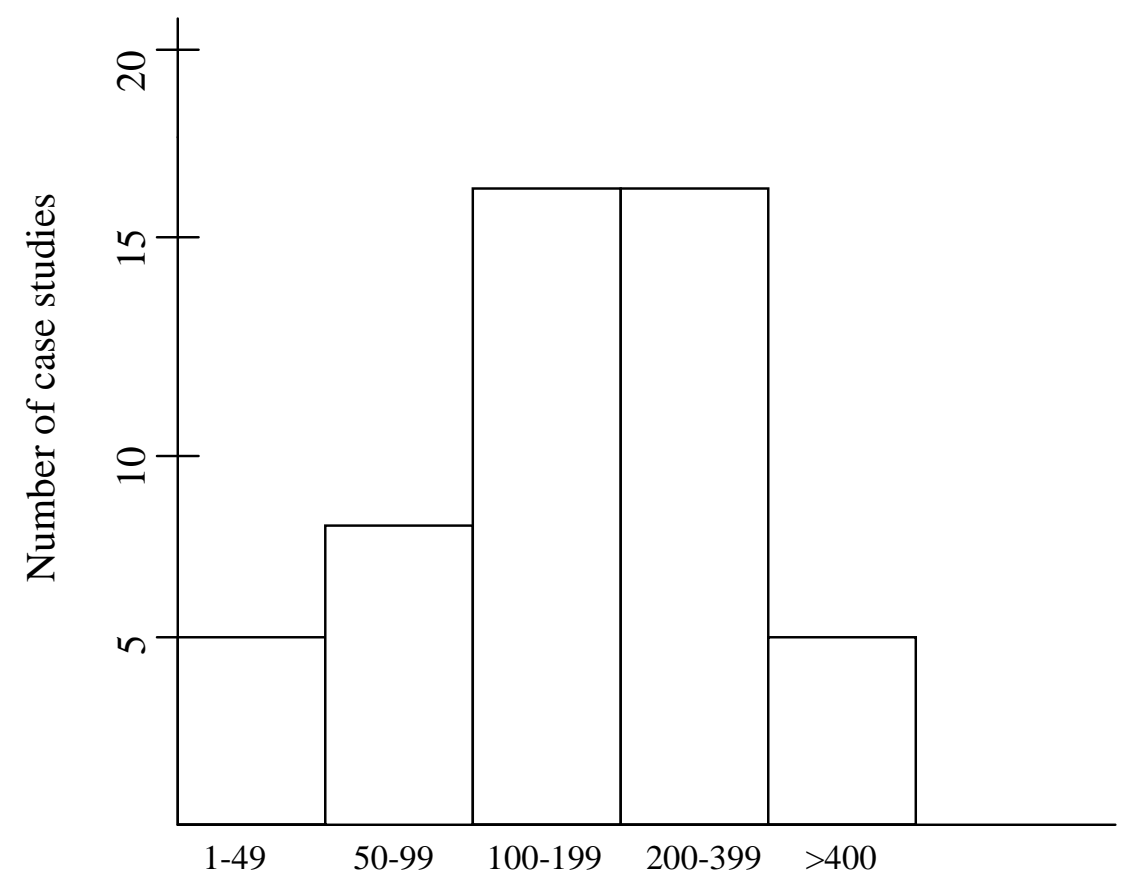

Price per person per day, US\$ $(n=52)$ 
Figure 2

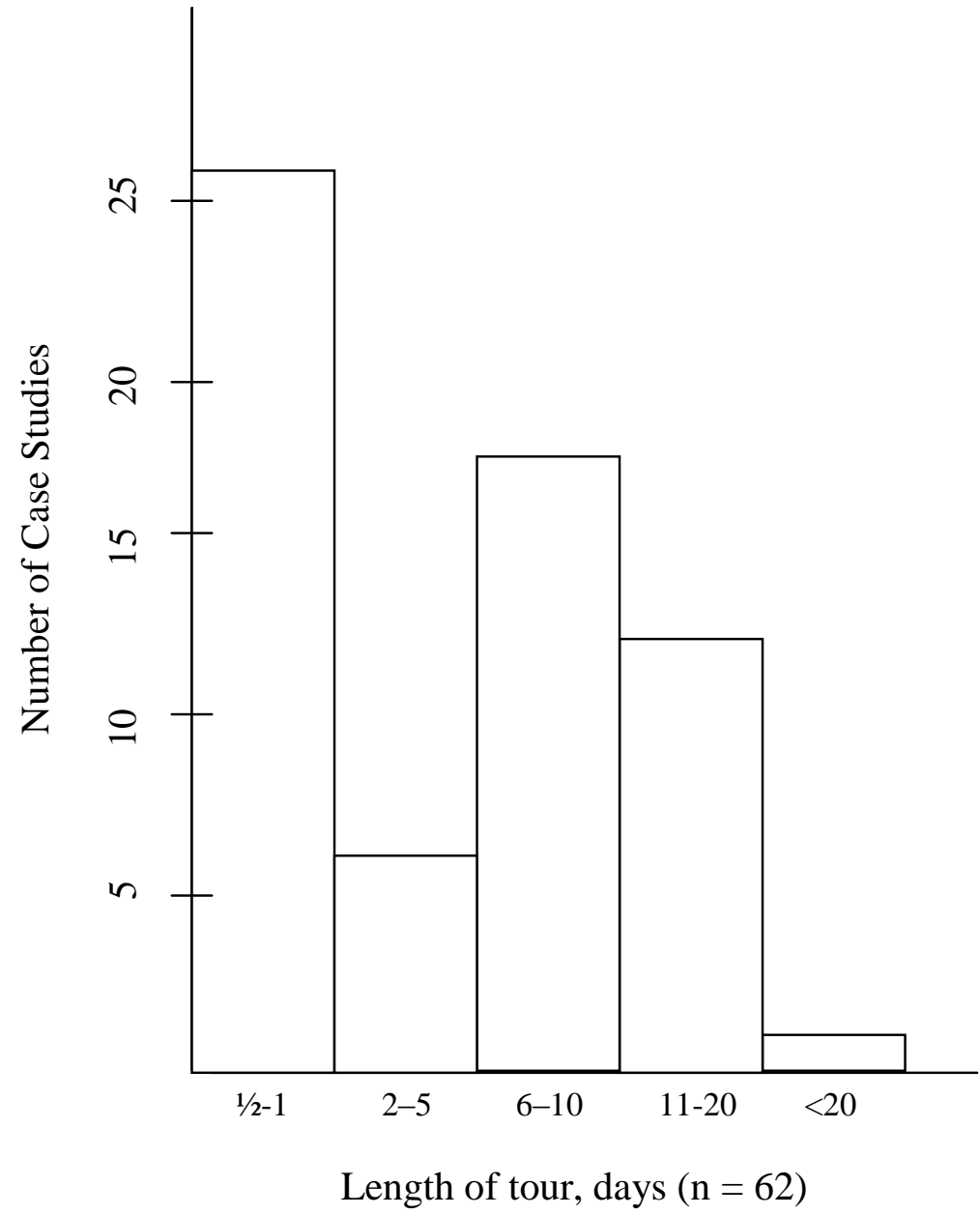

